\title{
PEMILIHAN SOFTWARE ANTIVIRUS UNTUK LABORATORIUM KOMPUTER AKUNTANSI DENGAN METODE AHP ( ANALYTICAL HIERARCHY PROCESS )
}

\author{
SEVTY WAHIDDIRANI SAPUTRI \\ Prodi Akuntansi S1, Fakultas Ekonomi, Universitas Pamulang, Banten \\ *Email: saputrisevty@gmail.com
}

\begin{abstract}
In this globalization era, there are many activities needed technology helps, computer technology is one of the sample. It's used to ease data operation or searching informations especially on learning program in the accounting computer laboratory. According to support that process, it's needed to select an antivirus software, to prevent some types of vyrus which could absorb the computer system, therefore the computer users will not be annoyed with some vyrus spreads the computers easily. SMK Jakarta IV nowadays still has some problems for getting informations about how to select some kinds of antivirus software such as : Kaspersky Antivirus, Eset Nod32 Antivirus, Avast Antivirus, Avira Antivirus, AVG Antivirus which the most effectively to support computer learning at SMK Jakarta IV. This observation use Analytical Hierarchy Process (AHP) method supported by Expert Choice 2000 application program as a media on selecting antivirus program. Based on the observation we have done, the result is An antivirus software which could help teaching process at school, in the accounting computer laboratory especially. AVG Antivirus is the right system from this analization which could implemented to support learning activities in the accounting computer school laboratory at SMK Jakarta IV therefore PC system could be safely protected from the viruses.
\end{abstract}

\section{Keywords : Decision Support System, Antivirus Software, Analytical Hierarchy Process (AHP)}

\section{PENDAHULUAN}

Dalam era globalisasi sekarang ini, aktivitas banyak dilakukan dengan bantuan teknologi seperti komputer. Guna mempermudah dalam pengelolaan data ataupun sekedar mencari berbagai macam informasi terutama dalam proses belajar mengajar di dalam laboratorium komputer akuntansi. Untuk mendukung proses tersebut dibutuhkan pemilihan suatu software antivirus, guna menghambat serta mencegah berbagai virus yang masuk kedalam sistem komputer agar aktivitas pengguna komputer pun tidak terganggu dengan banyaknya virus-virus yang dengan mudah menyebar.Penggunaan teknologi komputer di Indonesia terutama di sekolah-sekolah terus meningkat. Maka dengan adanya penelitian tersebut diharapkan proses belajar mengajar tidak terganggu akibat virus-virus yang masuk ke dalam sistem komputer laboratorium sekolah. Salah satu aspek yang mendukung kegiatan belajar mengajar dalam laboratorium sekolah adalah kenyamanan menggunakan komputer. Bagian operasional sekolah harus memutuskan software antivirus apa yang akan di pakai sesuai dengan kriteria yang di tentukan pihak sekolah dan juga mempertimbangkan aspek teknis di dalamnya. Kadang kesulitan yang dihadapi adalah bagaimana memilih perangkat software antivirus dengan biaya rendah namun memiliki kemampuan teknologi sesuai dengan perkembangan teknologi sekarang khususnya software antivirus. Berdasarkan permasalahan di atas peneliti sangat tertarik untuk memberi solusi bagi pihak sekolah SMK Jakarta IV dalam menghadapi permasalahannya agar dapat membuat keputusan yang tepat dalam memilih software antivirus yang akan digunakan di laboratorium komputer akuntansi untuk 
memenuhi kegiatan belajar mengajar serta mempersingkat waktu dalam pengambilan keputusan tersebut. Untuk itu peneliti akan melakukan penelitian di bidang teknologi informasi khususnya penggunaan Sistem Pengambilan Keputusan (SPK) berbasis AHP (Analytical Hierarchy Process) sangat tepat digunakan untuk mengatasi masalah unstructure yang ditemui saat memilih produk yang tepat berdasarkan berbagai macam kriteria, selain itu AHP juga mempunyai kemampuan untuk memecahkan masalah yang multi-objektif dan multi-kriteria yang berdasar pada perbandingan preferensi dari setiap elemen dalam hirarki Oyku Alanbay dari Istanbul, Turky, Bilgi University (2005), melakukan penelitian terhadap proses seleksi aplikasi perangkat lunak. Sistem Pengambilan Keputusan (SPK) biasa disebut juga dengan Decision Support System (DSS) adalah sistem berbasis komputer yang menyajikan dan memproses informasi yang memungkinkan pembuatan keputusan menjadi lebih produktif, dinamis dan inofatif. DSS dengan metode Analytical Hierarchy Process (AHP) dapat menjadi solusi dalam melakukan penilaian terhadap pemilihan software antivirus. Keberadaan hierarki memungkinkan dipecahnya masalah kompleks atau tidak terstruktur dalam sub-sub masalah, lalu menyusunnya menjadi suatu bentuk hirarki. Salah satu keunggulan AHP adalah dapat digambarkan secara grafis sehingga mudah dipahami oleh semua pihak yang terlibat dalam pengambilan keputusan.

\section{TINJAUAN PUSTAKA}

\section{Sistem Penunjang Keputusan (SPK)}

Sistem Pendukung Keputusan (SPK) atau Decision Support System (DSS) pertama kali diperkenalkan oleh Michael S. Scott Marton pada awal tahun 1970-an, yang selanjutnya dikenal dengan istilah Management Decision Systems. Konsep SPK ditandai dengan sistem interaktif berbasis komputer yang membantu pengambulan keputusan dengan memanfaatkan data dan model untuk menyelesaikan masalah yang bersifat tidak terstruktur dan semi terstruktur. Pada proses pengambilan keputusan, pengolahan data dan informasi yang dilakukan bertujuan untuk menghasilkan berbagai alternatif keputusan yang dapat diambil. SPK yang merupakan penerapan dari sistem informasi ditujukan hanya sebagai alat bantu manajemen dalam pengambilan keputusan dalam membuat keputusan, melainkan hanyalah sebagai alat bantu pengambil keputusan dalam melaksanakan tugasnya. SPK dirancang untuk menghasilkan berbagai macam alternatif yang ditawarkan kepada para pengambil keputusan dalam melaksanakan tugasnya. Sehingga dapat dikatakan bahwa SPK memberikan manfaat bagi manajemen dalam hal meningkatkan efektivitas dan efisiensi kerjanya terutama dalam proses pengambilan keputusan. Di samping itu, SPK menyatukan kemampuan komputer dalam pelayanan interaktif terhadap penggunanya dengan adanya proses pengolahan atau pemanipulasian data yang memanfaatkan model atau aturan yang tidak terstruktur sehingga menghasilkan alternatif keputusan yang situasional.

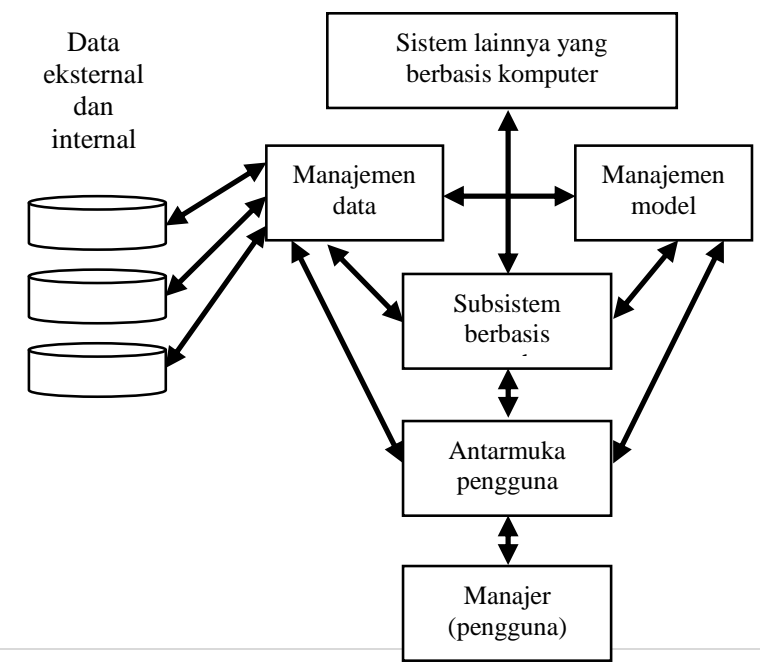




\section{Gambar 1. Model Konseptual SPK}

\section{Analytical Hierarchy Process (AHP)}

Dalam menyelesaikan permasalahan dengan AHP ada beberapa prinsip yang harus dipahami, diantaranya adalah:

1. Membuat Hirarki

Sistem yang kompleks bisa dipahami dengan memecahnya menjadi elemen-elemen pendukung, menyusun elemen secara hirarki, dan menggabungkannya atau mensistensisnya.

Untuk lebih jelasnya dapat dilihat pada gambar dibawah ini :

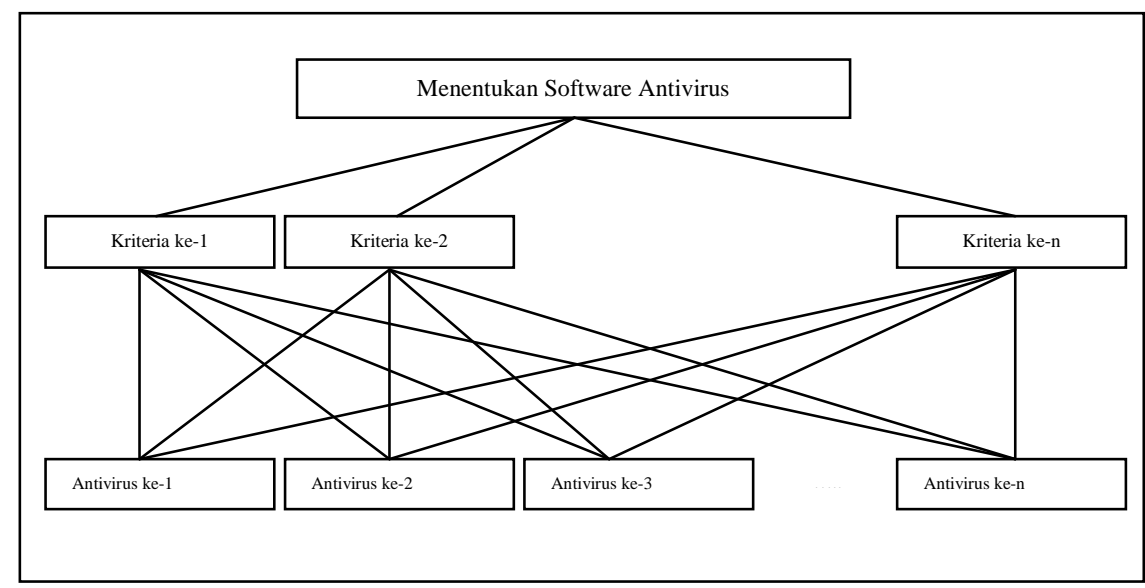

\section{Gambar 2. Struktur Hirarki AHP pada Kajian Pemilihan Software Antivirus untuk Laboratorium Komputer Akuntansi}

Keterangan Gambar :

a. Hirarki terbawah adalah nama-nama Software Antivirus SMK Jakarta IV.

b. Hirarki kedua adalah kriteria-kriteria yang dipakai untuk menganalisis Software Antivirus yang terdiri dari AVG Antivirus, Avast Antivirus, Avira Antivirus, Smadav Antivirus.

c. Hirarki ketiga adalah hirarki yang berisi Software Antivirus dengan prioritas tertinggi.

\section{Penilaian Kriteria dan Alternatif}

Tabel Intensitas Kepentingan

\begin{tabular}{cl}
\hline $\begin{array}{c}\text { Intensitas } \\
\text { Kepentingan }\end{array}$ & \multicolumn{1}{c}{ Keteranagan } \\
\hline 1 & $\begin{array}{l}\text { Kedua elemen sama pentingnya, dua elemen mempunyai } \\
\text { pengaruh sama besar. }\end{array}$ \\
& $\begin{array}{l}\text { Elemen yang satu sedikit lebih penting daripada elemen } \\
\text { yang lainnya, pengalaman dan penilaian sedikit }\end{array}$ \\
& menyokong satu elemen dibandingkan elemen yang \\
lainnya. & Elemen yang satu lebih penting daripada yang lainnya, \\
pengalaman dan penilaian sangat kuat menyokong satu \\
elemen dibandingkan elemen yang lainnya. \\
5 & $\begin{array}{l}\text { Satu elemen jelas lebih mutlak penting daripada elemen } \\
\text { lainnya, satu elemen yang kuat disokong dan dominan } \\
\text { terlihat dalam praktek. } \\
\text { Satu elemen mutlak penting daripada elemen lainnya, }\end{array}$
\end{tabular}


bukti yang mendukung elemen yang satu terhadao elemen lain memiliki tingkat penegasan tertinggi yang mungkin menguatkan.

Nila-nilai antara dua nilai pertimbangan-pertimbangan

2, 4, 6, 8 yang berdekatan, nilai ini diberikan bila ada dua kompromi di antara 2 pilihan.

Jika untuk aktivitas $\mathrm{X}$ mendapat satu angka dibanding

Kebalikan dengan aktivitas $\mathrm{Y}$, maka $\mathrm{Y}$ mempunyai nilai kebalikannya dibanding dengan $\mathrm{X}$.

\section{Penyelesaian AHP dengan Aplikasi Expert Choice 2000}

Expert Choice 2000 merupakan perangkat lunak yang dapat digunakan untuk perhitungan pemecahan persoalan dengan AHP sebagai Expert Choice. Pada penulisan tesis ini digunakan analisa ganda dengan perhitungan sesuai formula dan juga perhitungan dengan menggunakan aplikasi Expert Choice 2000. Tujuan dilakukan analisis ganda ini adalah untuk membandingkan dan membuktikan analisa perhitungan sesuai dengan aplikasi Expert Choice yang sudah teruji kehandalannya. Dalam penerapan metode AHP adalah memilih alternatif beradasarkan beberapa kriteria dengan jenis aplikasi yang berbeda-beda.

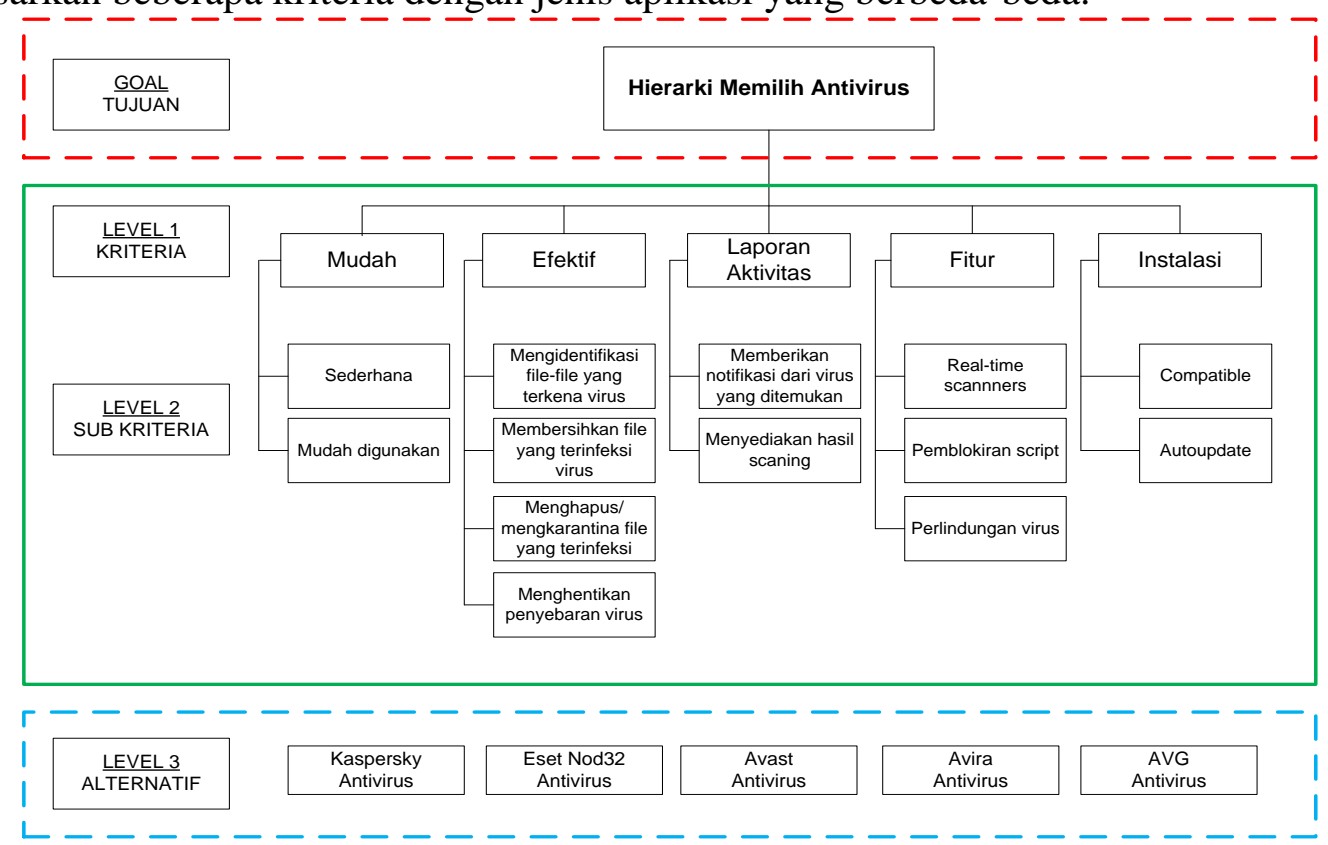

Gambar 3. Model AHP Pemilihan Software Antivirus

\section{Kerangka Konsep}

Dalam melakukan pemilihan software antivirus untuk laboratorium komputer akuntansi sekolah di SMK Jakarta IV menggunakan kriteria dan sub kriteria yang telah digunakan oleh ([Okyu Alanbay 2005]). Kriteria dan sub kriteria terbagi menjadi lima bagian besar yaitu, Mudah, Efektif, Laporan Aktivitas,Instalasi dan Fitur.

Kerangka konsep dalam pemilihan Software Antivirus untuk pembelajaran didalam Laboratorium KomputerAkuntansi dapat dilihat sebagai berikut : 


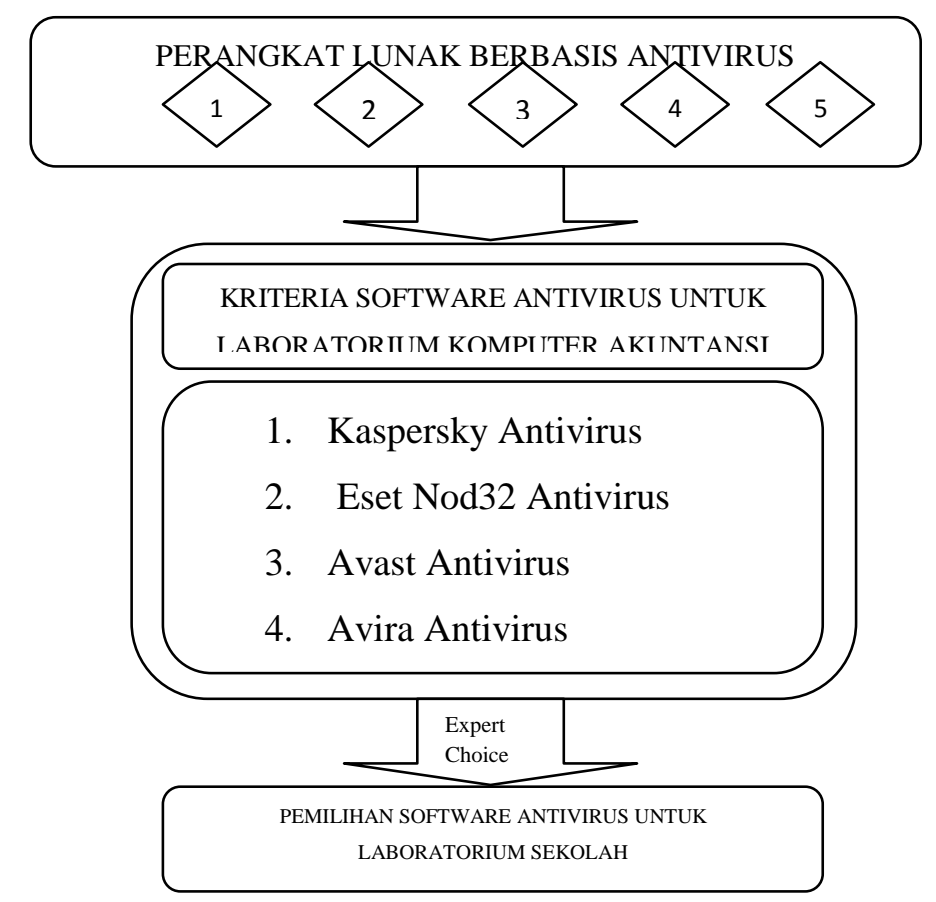

Gambar 4. Kerangka Pemikiran

\section{METODE PENELITIAN}

Berdasarkan jenis aplikasi yang digunakan dalam penelitian ini menunjukkan bahwa penelitian yang dilakukan oleh peneliti merupakan penelitian terapan. Hasil atau output dari penelitian ini akan diterapkan untuk menyelesaikan masalah dalam pemilihan jenis usaha.:

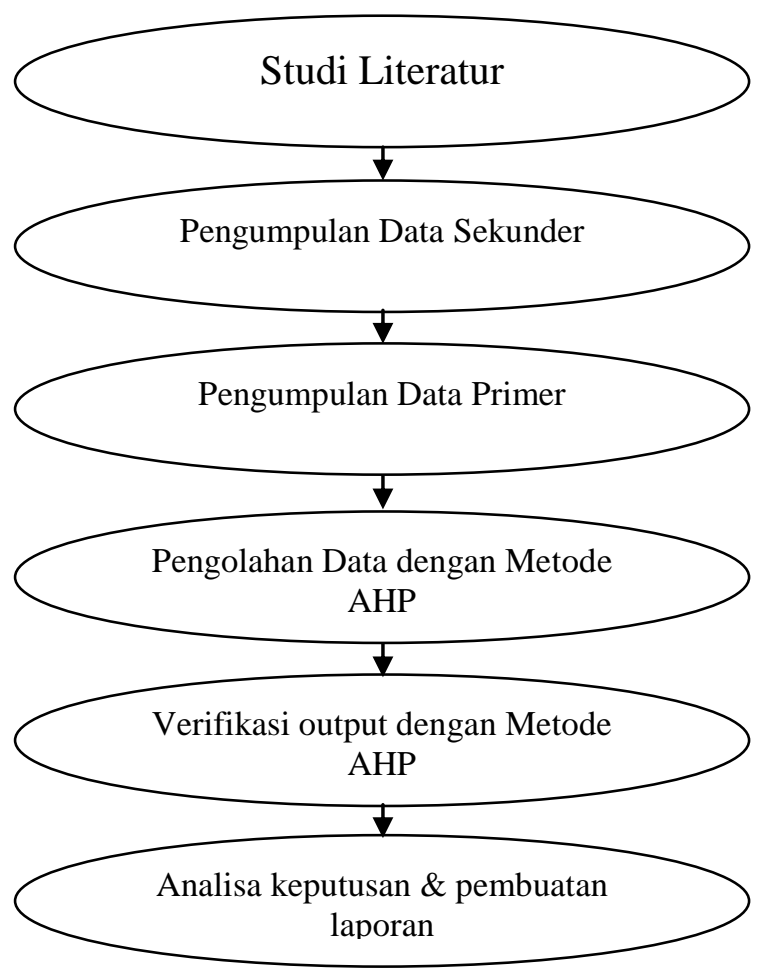




\section{Gambar 5. Metodologi Penelitian}

\section{HASIL PENELITIAN DAN PEMBAHASAN Gambaran Umum Penelitian}

Metode yang dipergunakan peneliti dalam penelitian ini adalah metode penelitian kuantitatif. Hal ini didasari pada proses pengambilan data melalui proses pembobotan seta penggunaan metode AHP dalam pengujian hipotesa yang dibuat. Tahapan metode pada penelitian ini diajukan pada Gambar 4. Pada Gambar 4. ditunjukkan bahwa metode penelitian yang akan dilakukan, dibagi ke dalam enam tahapan yaitu studi literatur, pengambilan data sekunder, pengambilan data primer, pengolahan data dengan AHP, verifikasi data hasil AHP, dan analisa keputusan dan pembuatan laporon.

\section{Populasi dan Sampel}

Populasi yang diambil dalam penelitian ini sebanyak 217 orang. Pengambilan sampel emnggunaka slovin, jadi dalam penelitian ini penulis menggunakan sampel sebanyak 82 orang responden, dimana 82 responden tersebut terdiri dari 1 orang kepala sekolah, 14 orang guru, dan 67 orang siswa/i SMK Jakarta IV. Metode yang dipergunakan oleh penulis dalam pengambilan sampel adalah Stratified Random Sampling. Teknik pengumpulan data yang dipergunakan oleh penulis adalah dengan mengumpulkan data dengan menggunakan kuesioner

\section{Analisa Data, Interpretasi, dan Implikasi \\ Hasil Pengolahan Data Responden}

1. Landasan kriteria dalam pemilihan software antivirus untuk laboratorium kompuer SMK Jakarta IV.

Dalam pemilihan perangkat lunak antivirus terdapat 5 kriteria yaitu Mudah, Efektif, Laporan Aktivitas, Fitur, Instalasi didapati hasil sebagai berikut :

\begin{tabular}{|c|}
\hline Priories withrespect tor \\
\hline
\end{tabular}
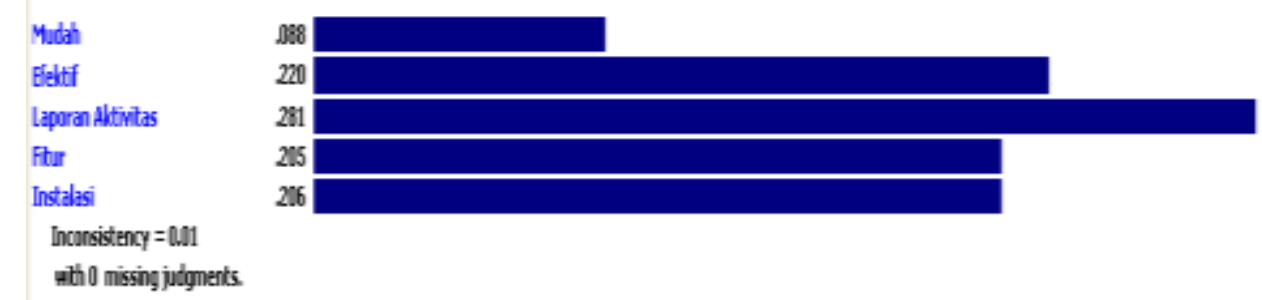

\section{Gambar 6. Prioritas Kriteria dalam Pemilihan Software Antivirus Beserta Nilai Bobotnya}

Dari hasil analisa mendapat gabungan responden menunjukkan bahwa kriteria laporan aktivitas (nilai bobot 0,281 atau sebanding dengan 28,1\% dari total kriteria) merupakan kriteria yang menurut responden paling penting pemilihan software antivirus untuk laboratorium komputer akuntansidi SMK Jakarta IV. Kriteria efektif menjadi pertimbangan kedua (nilai bobot 0,220 atau sebanding dengan $22 \%$ dari total kriteria) dalam pemilihan software antivirus untuk laboratorium komputer akuntansidi SMK Jakarta IV. Kriteria instalasi menjadi pertimbangan ketiga (nilai bobot 0,206 atau sebanding dengan 20,6\% dari total kriteria) dalam pemilihan software antivirus untuk laboratorium komputer akuntansidi SMK Jakarta IV. Kriteria fitur menjadi pertimbangan keempat (nilai bobot 0,205 atau sebanding dengan $20,5 \%$ dari total kriteria) dalam pemilihan software antivirus untuk 
laboratorium komputer akuntansidi SMK Jakarta IV. Sedangkan kriteria mudah merupakan kriteria terakhir (nilai bobot 0,088 atau sebanding dengan 8,8\% dari total kriteria) yang dipertimbangkan dalam pemilihan software antivirus untuk laboratorium sekolah.

2. Landasan sub kriteria menjadi pertimbangan dalam kriteria Mudah

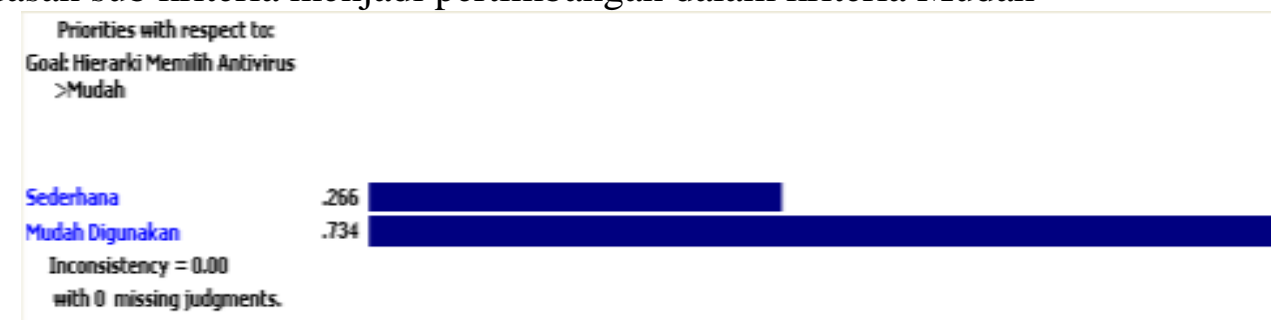

\section{Gambar 7. Sub Kriteria dari Kriteria Mudah}

Dari hasil analisa mendapat gabungan responden menunjukkan bahwa sub kriteria mudah digunakan (nilai bobot 0,734 atau sebanding dengan 73,4\% dari total sub kriteria dalam kriteria mudah) merupakan sub kriteria yang menurut responden paling penting dalam kriteria mudah dalam pemilihan software antivirus unthk laboratorium komputer akuntansidi SMK Jakarta IV. Sub kriteria terakhir yang menjadi pertimbangan adalah sub kriteria sederhana (nilai bobot 0,266 atau sebanding dengan 26,6\% dati total sub kriteria dalam kriteria mudah) merupakan sub kriteria yang menurut responden paling penting dalam kriteria mudah dalam pemilihan software antivirus untuk laboratorium komputer akuntansidi SMK Jakarta IV.

3. Landasan sub kriteria yang menjadi pertimbangan dalam kriteria Efektif
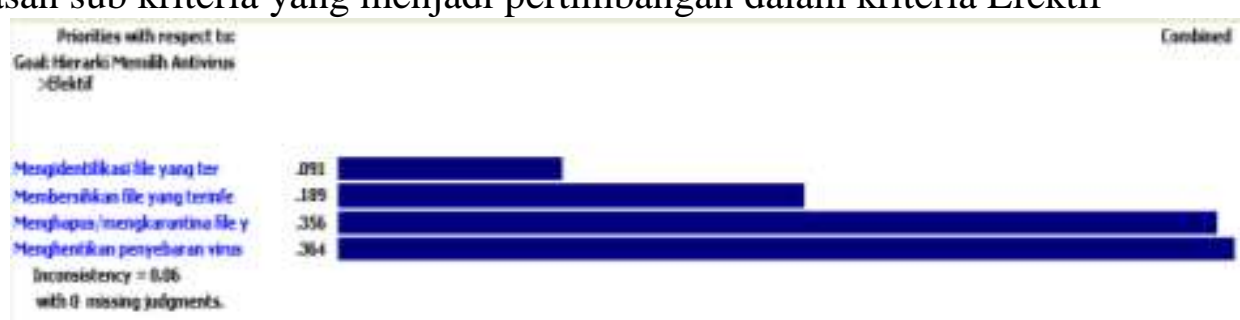

\section{Gambar 8. Sub Kriteria dari Kriteria Efektif}

Dari hasil analisa mendapat gabungan responden menunjukkan bahwa sub kriteria menghentikan penyebaran virus (nilai bobot 0,364 atau sebanding dengan 36,4\% dari total sub kriteria dalam kriteria efektif) merupakan sub kriteria yang menurut responden paling penting dalam kriteria efektif dalam pemilihan software antivirus untuk laboratorium komputer akuntansidi SMK Jakarta IV. Sub kriteria menghapus/mengkarantina file yang terinfeksi menjadi prioritas kedua (nilai bobot 0,356 atau sebanding dengan 35,6\% dari total sub kriteria dalam kriteria efektif) merupakan sub kriteria yang menurut responden paling penting dalam kriteria efektif dalam pemilihan software antivirus untuk laboratorium komputer akuntansidi SMK Jakarta IV. Sub kriteria membersihkan file yang terinfeksi virus menjadi prioritas ketiga (nilai bobot 0,189 atau sebanding dengan 18,9\% dari total sub kriteria efektif) merupakan sub kriteria yang menurut responden paling penting dalam kriteria efektif dalam pemilihan software antivirus untuk laboratorium komputer akuntansidi SMK Jakarta IV. Sub kriteria terakhir yang menjadi pertimbangan adalah sub kriteria mengidentifikasi file yang terkena virus (nilai bobot 0,091 atau sebanding dengan 9,1\% dari total sub kriteria dalam kriteria efektif) merupakan sub kriteria yang menurut responden paling penting dalam kriteria efektif dalam pemilihan software antivirus untuk laboratorium komputer akuntansidi SMK Jakarta IV.

4. Landasan sub kriteria yang menjadi pertimbangan dalam kriteria Laporan Aktivitas 


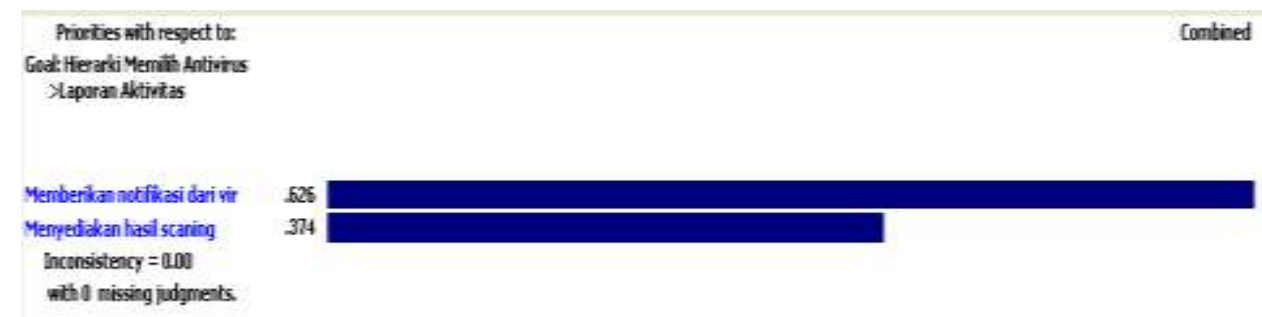

\section{Gambar 9. Subkriteria dari Kriteria Laporan Aktivitas}

Dari hasil analisa mendapat gabungan responden menunjukkan bahwa sub kriteria memberikan notifikasi dari virus yang ditemukan (nilai bobot 0,626 atau sebanding dengan $62,6 \%$ dari total sub kriteria dalam kriteria laporan aktivitas) merupakan sub kriteria yang menurut responden paling penting dalam kriteria laporan aktivitas dalam pemilihan software antivirus untuk laboratorium komputer akuntansidi SMK Jakarta IV. Sub kriteria terakhir yang menjadi pertimbangan adalah sub kriteria menyediakan hasil scanning (nilai bobot 0,374 atau sebanding dengan $37,4 \%$ dari total sub kriteria laporan aktivitas) merupakan sub kriteria yang menurut responden paling penting dalam kriteria laporan aktivitas dalam pemilihan software antivirus untuk laboratorium komputer akuntansidi SMK Jakarta IV.

5. Landasan sub kriteria yang menjadi pertimbangan dalam kriteria Fitur

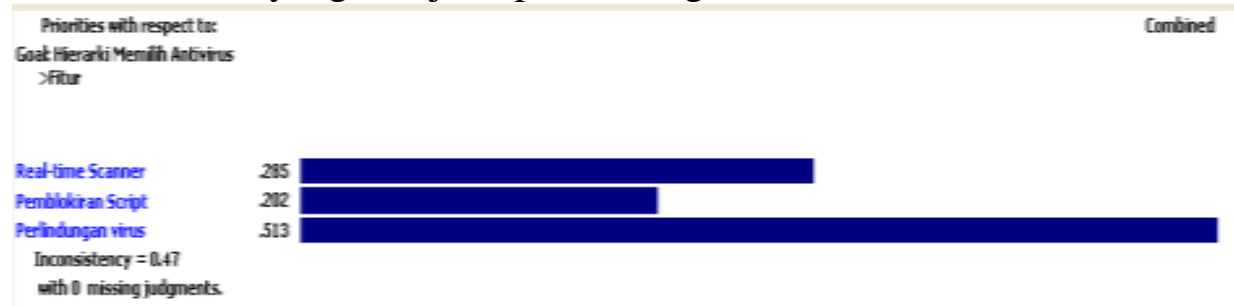

Gambar 10. Sub Kriteria dari Kriteria Fitur

Dari hasil analisa mendapat gabungan responden menunjukkan bahwa sub kriteria perlindungan virus (nilai bobot 0,513 atau sebanding dengan $51,3 \%$ dari total sub kriteria dalam kriteria fitur) merupakan sub kriteria yang menurut responden paling penting dalam kriteria fitur dalam pemilihan software antivirus untuk laboratorium komputer akuntansidi SMK Jakarta IV. Sub kriteria real-time scanners menjadi prioritas ke dua (nilai bobot 0,285 atau sebanding dengan $28,5 \%$ dari total sub kriteria dalam kriteria fitur) merupakan sub kriteria yang menurut responden paling penting dalam kriteria fitur dalam pemilihan software antivirus untuk laboratorium komputer akuntansidi SMK Jakarta IV. Sub kriteria terakhir yang menjadi pertimbangan adalah sub kriteria pemblokiran script (nilai bobot 0,202 atau sebanding dengan 20,2\% dari total sub kriteria laporan aktivitas) merupakan sub kriteria yang menurut responden paling penting dalam kriteria fitur dalam pemilihan software antivirus untuk laboratorium komputer akuntansidi SMK Jakarta IV.

6. Landasan sub kriteria yang menjadi pertimbangan dalam kriteria Instalasi

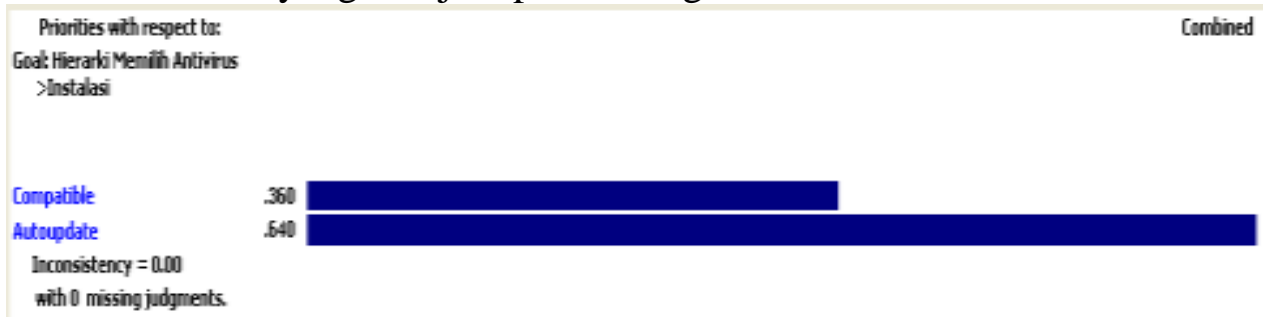

\section{Gambar 11. Sub Kriteria dari Kriteria Instalasi}

Dari hasil analisa mendapat gabungan responden menunjukkan bahwa sub kriteria autoupdate (nilai bobot 0,640 atau sebanding dengan $64 \%$ dari total sub kriteria dalam kriteria instalasi) merupakan sub kriteria yang menurut responden paling penting dalam kriteria 
instalasi dalam pemilihan software antivirus untuk laboratorium komputer akuntansidi SMK Jakarta IV. Sub kriteria terakhir yang menjadi pertimbangan adalah sub kriteria compatible (nilai bobot 0,460 atau sebanding dengan $46 \%$ dari total sub kriteria instalasi) merupakan sub kriteria yang menurut responden paling penting dalam kriteria instalasi dalam pemilihan software antivirus untuk laboratorium komputer akuntansidi SMK Jakarta IV.

7. Landasan Atrnatif Software Antivirus untuk Laboratorium Komputer Akuntansi yang Dipilih Berdasarkan Kriteria dan Sub Kriteria

a. Alternatif Software Antivirus untuk Laboratorium Komputer Akuntansi yang Dipilih Berdasarkan Kriteria Mudah, Sub Kriteria Sederhana.

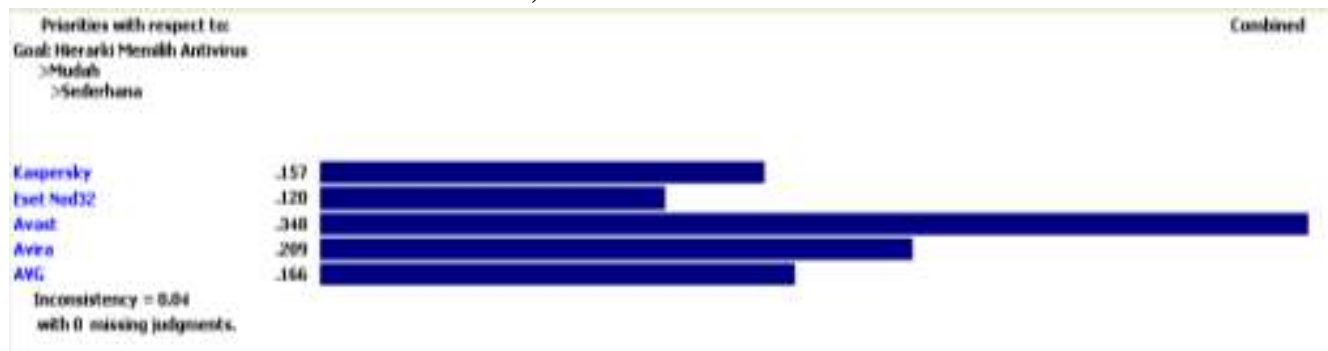

\section{Gambar 12. Nilai Bobot Prioritas Alternatif Software Antivirus berdasarakan KriteriaMudah dalam sub criteria Sederhana}

Berdasarkan pendapat seluruh responden untuk kriteria mudah sub kriteria sederhana diperoleh hasil bahwa software Avast Antivirus merupakan pilihan pertama sebagai software antivirus untuk laboratorium komputer akuntansidi SMK Jakarta IV. Pilihan kedua adalah Avira Antivirus, pilihan ketiga adalah AVG Antivirus, pilihan keempat adalah Kaspersky Antivirus, serta pilihan terakhir adalah Eset Nod32 Antivirus.

b. Alternatif Software Antivirus untuk Laboratorium Komputer Akuntansiyang Dipilih Berdasarkan Kriteria Mudah, Sub Kriteria Mudah Digunakan.

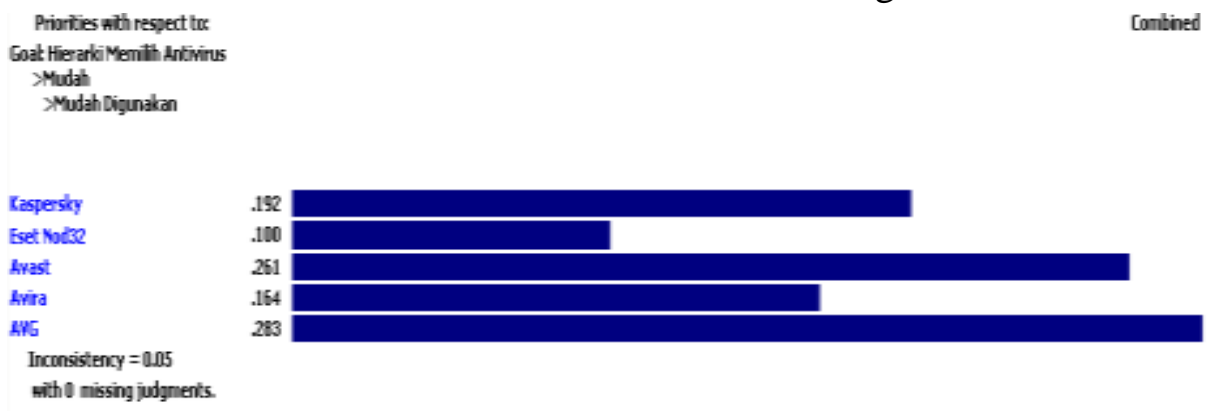

\section{Gambar 13. Nilai Bobot Prioritas Alternatif Software Antivirus berdasarakan KriteriaMudah dalam sub kriteria Mudah Digunakan}

Berdasarkan pendapat seluruh responden untuk kriteria mudah sub kriteria sederhana diperoleh hasil bahwa software AVG Antivirus merupakan pilihan pertama sebagai software antivirus untuk labaratorium komputer di SMK Jakarta IV. Pilihan kedua adalah Avast Antivirus, pilihan ketiga adalah Kaspersky Antivirus, pilihan keempat adalah Avira Antivirus, serta pilihan terakhir adalah Eset Nod32 Antivirus.

c. Alternatif Software Antivirus untuk Laboratorium Komputer Akuntansi yang Dipilih Berdasarkan Kriteria Efektif, Sub Kriteria Mengidentifikasi File yang Terkena Virus. 

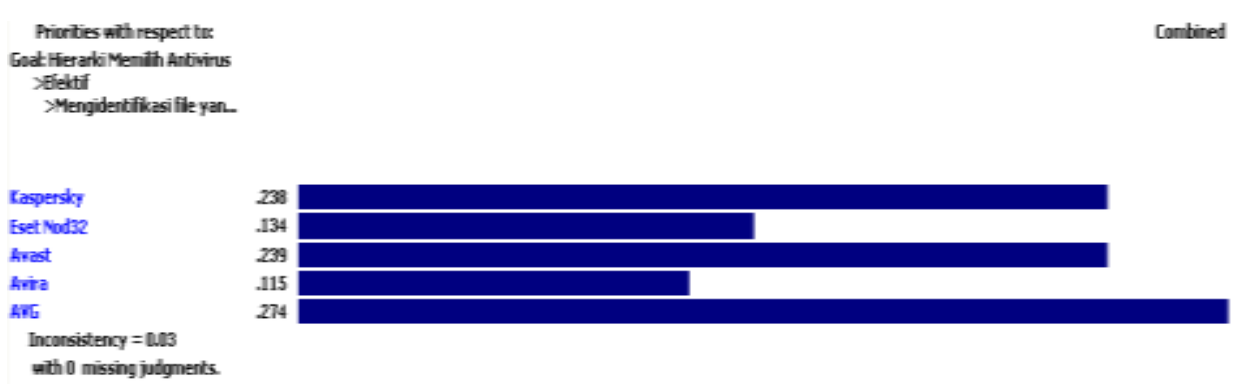

\section{Gambar 14. Nilai Bobot Prioritas Alternatif Software Antivirus berdasarakan Kriteria} Efektif dalam sub kriteria Mengidentifikasi File yang Teridentifikasi Virus

Berdasarkan pendapat seluruh responden untuk kriteria efektif sub kriteria mengidentifikasi file yang teridentifikasi virus diperoleh hasil bahwa software AVG Antivirus merupakan pilihan pertama sebagai software antivirus untuk labaratorium komputer di SMK Jakarta IV. Pilihan kedua adalah Avast Antivirus, pilihan ketiga adalah Kaspersky Antivirus, pilihan keempat adalah Eset Nod32 Antivirus, serta pilihan terakhir adalah Avira Antivirus.

d. Alternatif Software Antivirus untuk Laboratorium Komputer Akuntansiyang Dipilih Berdasarkan Kriteria Efektif, Sub Kriteria Mebersihkan File yang Terinfeksi Virus.
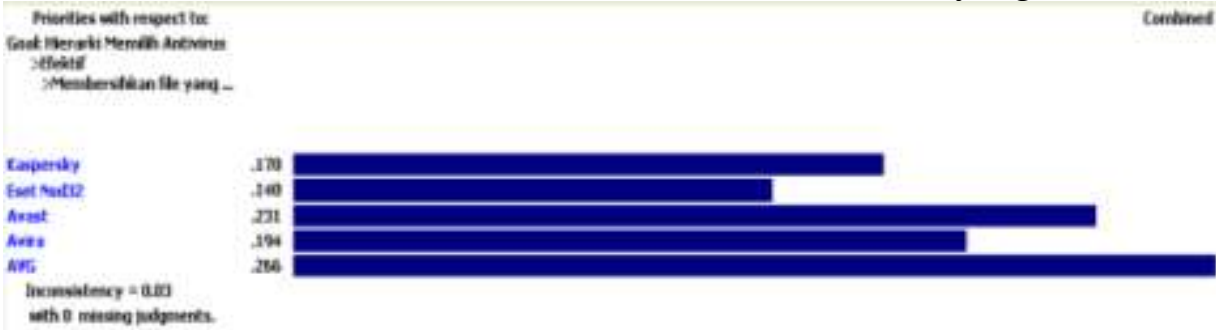

Gambar 15. Nilai Bobot Prioritas Alternatif Software Antivirus berdasarakan Kriteria Efektif dalam sub kriteria Membersihkan File yang Teridnfeksi Virus

Berdasarkan pendapat seluruh responden untuk kriteria efektif sub kriteria membersihkan file yang terinfeksi virus diperoleh hasil bahwa software AVG Antivirus merupakan pilihan pertama sebagai software antivirus untuk labaratorium komputer di SMK Jakarta IV. Pilihan kedua adalah Avast Antivirus, pilihan ketiga adalah Kaspersky Antivirus, pilihan keempat adalah Avira Antivirus, serta pilihan terakhir adalah Eset Nod32 Antivirus.

e. Alternatif Software Antivirus untuk Laboratorium Komputer Akuntansiyang Dipilih Berdasarkan Kriteria Efektif, Sub Kriteria Menghapus/Mengkarantina File yang Terinfesi Virus.
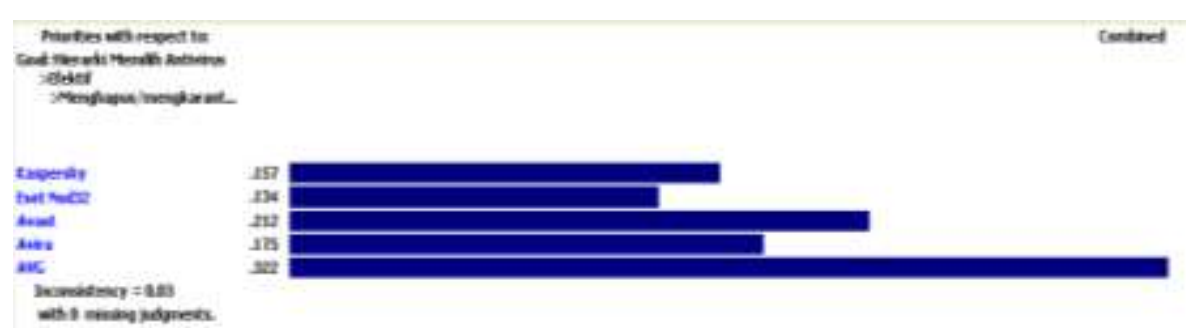

Gambar 16. Nilai Bobot Prioritas Alternatif Software Antivirus berdasarakan Kriteria Efektif dalam sub kriteria Menghapus/Mengkarantina File yang Terinfeksi Virus 
Berdasarkan pendapat seluruh responden untuk kriteria efektif sub kriteria menghapus/mengkarantina file yang terinfeksi virus diperoleh hasil bahwa software AVG Antivirus merupakan pilihan pertama sebagai software antivirus untuk labaratorium komputer di SMK Jakarta IV. Pilihan kedua adalah Avast Antivirus, pilihan ketiga adalah Kaspersky Antivirus, pilihan keempat adalah Avira Antivirus, serta pilihan terakhir adalah Eset Nod32 Antivirus.

f. Alternatif Software Antivirus untuk Laboratorium Komputer Akuntansiyang Dipilih Berdasarkan Kriteria Efektif, Sub Kriteria Menghentikan Penyebaran Virus.
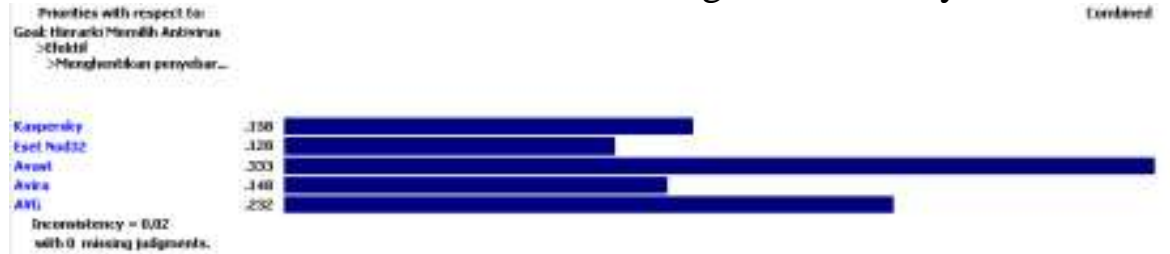

\section{Gambar 17. Nilai Bobot Prioritas Alternatif Software Antivirus berdasarakan Kriteria Efektif dalam sub kriteria Menghentikan Penyebaran Virus}

Berdasarkan pendapat seluruh responden untuk kriteria efektif sub kriteria menghentikan penyebaran virus diperoleh hasil bahwa software Avast Antivirus merupakan pilihan pertama sebagai software antivirus untuk labaratorium komputer di SMK Jakarta IV. Pilihan kedua adalah AVG Antivirus, pilihan ketiga adalah Kaspersky Antivirus, pilihan keempat adalah Avira Antivirus, serta pilihan terakhir adalah Eset Nod32 Antivirus.

g. Alternatif Software Antivirus untuk Laboratorium Komputer Akuntansi yang Dipilih Berdasarkan Kriteria Laporan Aktivitas, Sub Kriteria Memberikan Notifikasi dari Virus yang Ditemukan.
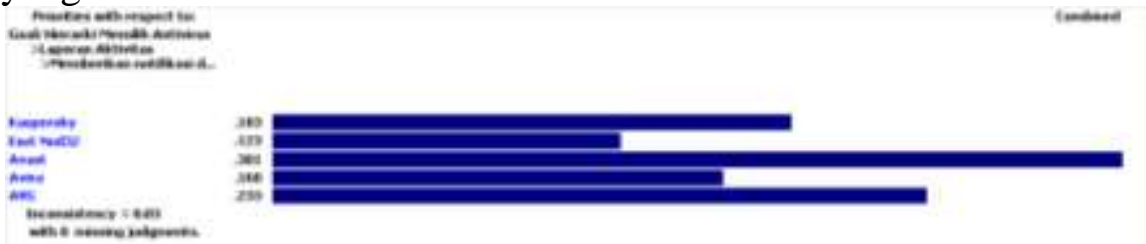

\section{Gambar 18. Nilai Bobot Prioritas Alternatif Software Antivirus berdasarakan Kriteria Laporan Aktivitas dalam sub kriteria Memberikan Notofikasi dari Virus yang Ditemukan}

Berdasarkan pendapat seluruh responden untuk kriteria laporan aktifitas sub kriteria memberikan notifikasi dari virus yang ditemukan diperoleh hasil bahwa software Avast Antivirus merupakan pilihan pertama sebagai software antivirus untuk labaratorium komputer di SMK Jakarta IV. Pilihan kedua adalah AVG Antivirus, pilihan ketiga adalah Kaspersky Antivirus, pilihan keempat adalah Avira Antivirus, serta pilihan terakhir adalah Eset Nod32 Antivirus.

h. Alternatif Software Antivirus untuk Laboratorium Komputer Akuntansi yang Dipilih Berdasarkan Kriteria Laporan Aktivitas, Sub Kriteria Menyediakan Hasil Scaning.
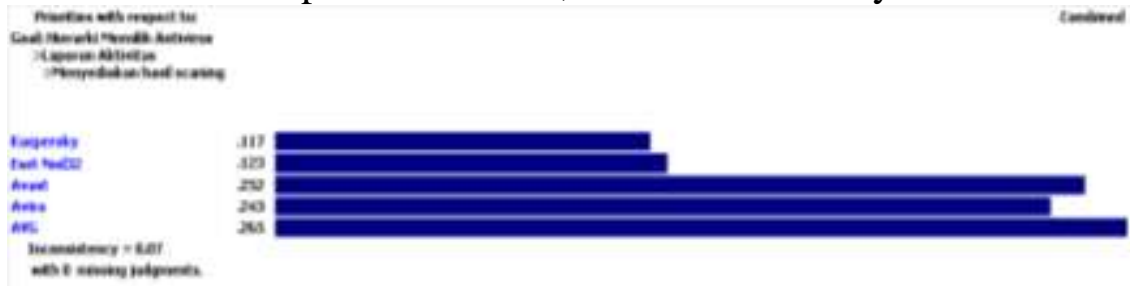


\section{Gambar 19. Nilai Bobot Prioritas Alternatif Software Antivirus berdasarakan Kriteria Laporan Aktivitas dalam sub kriteria Menyediakan Hasil Scanning}

Berdasarkan pendapat seluruh responden untuk kriteria laporan aktifitas sub kriteria menyediakan hasil scaning diperoleh hasil bahwa software AVG Antivirus merupakan pilihan pertama sebagai software antivirus untuk labaratorium komputer di SMK Jakarta IV. Pilihan kedua adalah Avast Antivirus, pilihan ketiga adalah Avira Antivirus, pilihan keempat adalah Eset Nod32 Antivirus, serta pilihan terakhir adalah Kaspersky Antivirus.

i. Alternatif Software Antivirus untuk Laboratorium Komputer Akuntansi yang Dipilih Berdasarkan Kriteria Fitur, Sub Kriteria Real-Time Scanners.
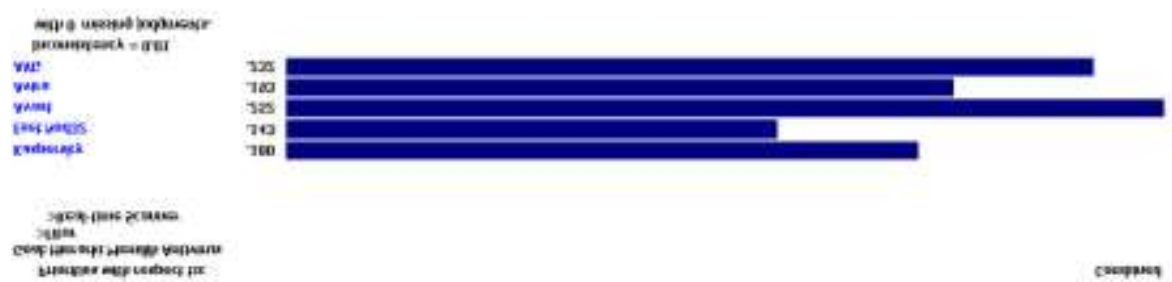

Gambar 20. Nilai Bobot Prioritas Alternatif Software Antivirus berdasarakan Kriteria Fitur dalam sub kriteria Real-Time Scanners

Berdasarkan pendapat seluruh responden untuk kriteria fitur sub kriteria real-time scanners diperoleh hasil bahwa software Avast Antivirus merupakan pilihan pertama sebagai software antivirus untuk labaratorium komputer di SMK Jakarta IV. Pilihan kedua adalah AVG Antivirus, pilihan ketiga adalah Avira Antivirus, pilihan keempat adalah Kaspersky Antivirus, serta pilihan terakhir adalah Eset Nod32 Antivirus.

j. Alternatif Software Antivirus untuk Laboratorium Komputer Akuntansi yang Dipilih Berdasarkan Kriteria Fitur, Sub Kriteria Pemblokiran Script.
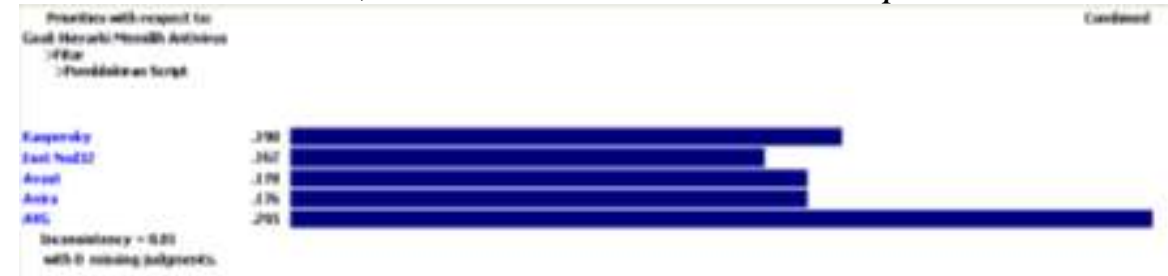

Gambar 21. Nilai Bobot Prioritas Alternatif Software Antivirus berdasarakan Kriteria Fitur dalam sub kriteria Pemblokiran Script

Berdasarkan pendapat seluruh responden untuk kriteria fitur sub kriteria pemblokiran script diperoleh hasil bahwa software AVG Antivirus merupakan pilihan pertama sebagai software antivirus untuk labaratorium komputer di SMK Jakarta IV. Pilihan kedua adalah Kaspersky Antivirus, pilihan ketiga adalah Avast Antivirus, pilihan keempat adalah Avira Antivirus, serta pilihan terakhir adalah Eset Nod32 Antivirus.

k. Alternatif Software Antivirus untuk Laboratorium Komputer Akuntansi yang Dipilih Berdasarkan Kriteria Fitur, Sub Kriteria Perlindungan Virus.
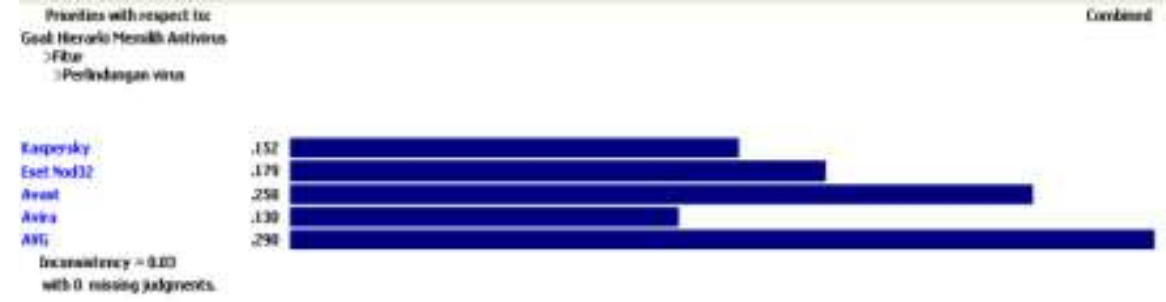
Gambar 22. Nilai Bobot Prioritas Alternatif Software Antivirus berdasarakan Kriteria Fitur dalam sub kriteria Perlindungan Virus

Berdasarkan pendapat seluruh responden untuk kriteria fitur sub kriteria perlindungan virus diperoleh hasil bahwa software AVG Antivirus merupakan pilihan pertama sebagai software antivirus untuk labaratorium komputer di SMK Jakarta IV. Pilihan kedua adalah Avast Antivirus, pilihan ketiga adalah Eset Nod32 Antivirus, pilihan keempat adalah Kaspersky Antivirus, serta pilihan terakhir adalah Avira Antivirus.

1. Alternatif Software Antivirus untuk Laboratorium Komputer Akuntansi yang Dipilih Berdasarkan Kriteria Instalasi, Sub Kriteria Compatible.

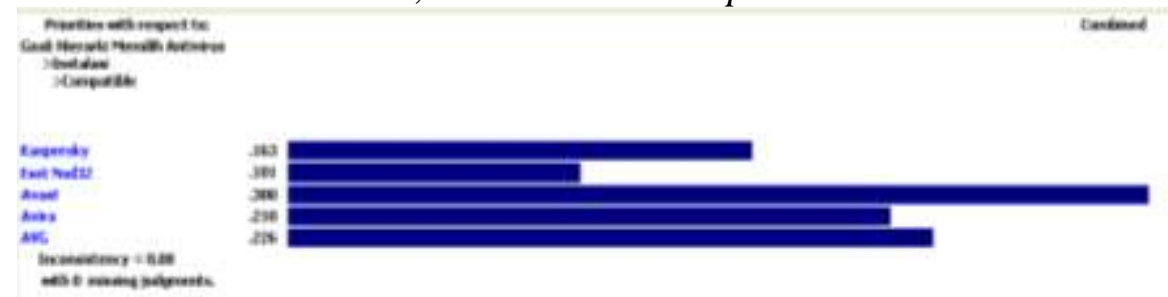

Gambar 23. Nilai Bobot Prioritas Alternatif Software Antivirus berdasarakan Kriteria Instalasi dalam sub kriteria Compatible

Berdasarkan pendapat seluruh responden untuk kriteria instalasi sub kriteria compatible diperoleh hasil bahwa software Avast Antivirus merupakan pilihan pertama sebagai software antivirus untuk labaratorium komputer di SMK Jakarta IV. Pilihan kedua adalah AVG Antivirus, pilihan ketiga adalah Avira Antivirus, pilihan keempat adalah Kaspersky Antivirus, serta pilihan terakhir adalah Eset Nod32 Antivirus.

m. Alternatif Software Antivirus untuk Laboratorium Komputer Akuntansi yang Dipilih Berdasarkan Kriteria Instalasi, Sub Kriteria Autoupdate.
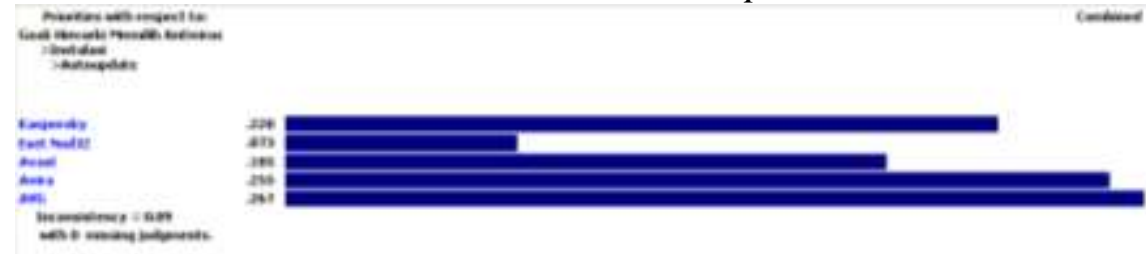

\section{Gambar 24. Nilai Bobot Prioritas Alternatif Software Antivirus berdasarakan Kriteria Instalasi dalam sub kriteria Autoupdate}

Berdasarkan pendapat seluruh responden untuk kriteria instalasi sub kriteria autoupdate diperoleh hasil bahwa software AVG Antivirus merupakan pilihan pertama sebagai software antivirus untuk labaratorium komputer di SMK Jakarta IV. Pilihan kedua adalah Avira Antivirus, pilihan ketiga adalah Kaspersky Antivirus, pilihan keempat adalah Avast Antivirus, serta pilihan terakhir adalah Eset Nod32 Antivirus.

\section{Bobot Alternatif}

Setelah melalui proses pengisian kuesioner oleh para Responden, dan melalui perhitungan penggabungan data Responden dengan menggunakan software expert choice 2000 diperoleh nilai bobot global prioritas alternatif berdasarkan sasaran pemilihan software antivirus seperti yang disajikan pada grafik berikut

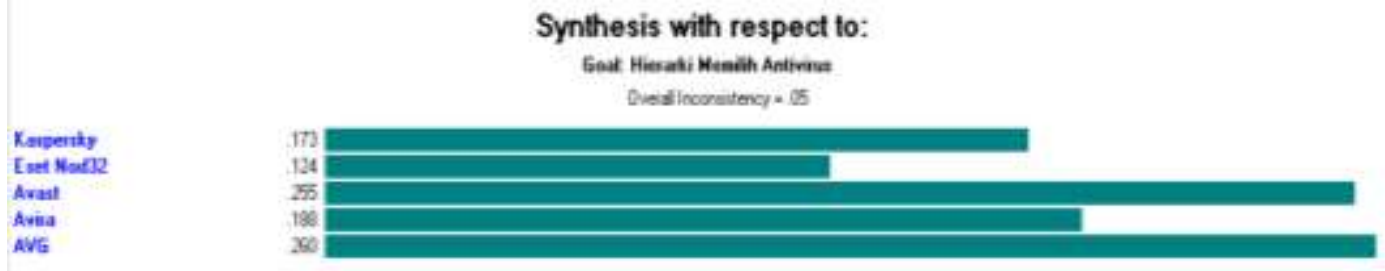




\section{Gambar IV.25. Nilai Bobot Global Prioritas Alternatif Berdasarkan Sasaran Pemilihan Software Antivirus untuk Laboratorium Komputer Akuntansidi SMK Jakarta IV}

Berdasarkan hasil yang diperoleh dari pengolahan data Responden didapat bahwa prioritas utama atau tertinggi alternatif pemilihan software antivirus untuk laboratorium komputer akuntansi di SMK Jakarta IV adalah AVG Antivirus dengan nilai bobot 0,260 atau sebanding dengan $26 \%$ dari total alternatif yang ditetapkan. Hasil nilai bobot alternatif ini terbukti sesuai dengan hipotesa yang dirumuskan bahwa AVG Antivirus merupakan software antivirus untuk laboratorium komputer akuntansi di SMK Jakarta IV. Kemudian prioritas kedua adalah Avast Antivirus dengan dengan nilai bobot 0,255 atau sebanding dengan 25,5\% dari total alternatif yang ditetapkan. Prioritas ketiga adalah Avira Antivirus dengan dengan nilai bobot 0,188 atau sebanding dengan $18,8 \%$ dari total alternatif yang ditetapkan. Prioritas keempat adalah Kaspersky Antivirus dengan dengan nilai bobot 0,173 atau sebanding dengan $17,3 \%$ dari total alternatif yang ditetapkan. Software antivirus yang terakhir adalah Eset Nod32 Antivirus dengan nilai bobot 0,124 atau sebanding dengan 12,4\% dari total alternatif yang ditetapkan.

\section{Inconsistency Ratio (CR)}

Inconsistency ratio atau rasio inkonsistensi data Responden merupakan parameter yang digunakan untuk memeriksa apakah perbandingan berpasangan telah dilakukan dengan konsekuen atau tidak. Rasio inkonsistensi data dianggap baik jika nila CR-nya $\leq 0.10$.

Untuk mengecek rasio inkonsistensi data responden, berikut ini ditampilkan nilai rasio inkonsistensi pada masing-masing matriks perbandingan.

Tabel 3. Rasio Inkonsistensi Perbandingan Antara Elemen Matriks Penggabungan Data Responden

\begin{tabular}{|c|c|c|}
\hline No & Matriks Perbandingan Elemen & $\begin{array}{l}\text { Nilai } \\
\text { CR }\end{array}$ \\
\hline 1 & $\begin{array}{l}\text { Perbandingan Pemilihan Software Antivirus untuk } \\
\text { Laboratorium Komputer Akuntansi di SMK Jakarta IV }\end{array}$ & 0,01 \\
\hline 2 & Level 1. Kriteia Mudah & 0,00 \\
\hline 3 & Level 1. Kriteria Efektif & 0,06 \\
\hline 4 & Level 1. Kriteria Laporan Aktivitas & 0,00 \\
\hline 5 & Level 1. Kriteria Fitur & 0,47 \\
\hline 6 & Level 1. Kriteria Instalasi & 0,00 \\
\hline 7 & Level 2. Kriteria Mudah - Sub Kriteria Sederhana & 0,04 \\
\hline 8 & $\begin{array}{l}\text { Level 2. Kriteria Mudah }- \text { Sub Kriteria Mudah } \\
\text { Digunakan }\end{array}$ & 0,05 \\
\hline 9 & $\begin{array}{l}\text { Level 2. Kriteria Efektif - Sub Kriteria Mengidentifikasi } \\
\text { File yang Terkena Virus }\end{array}$ & 0,03 \\
\hline 10 & $\begin{array}{l}\text { Level 2. Kriteria Efektif - Sub Kriteria Membersihkan } \\
\text { File yang Terinfeksi Virus }\end{array}$ & 0,03 \\
\hline 11 & $\begin{array}{l}\text { Level 2. Kriteria Efektif }-\underset{\text { Sub }}{\text { Kriteria }} \\
\text { Menghapus/Mengkarantina File yang Terinfeksi }\end{array}$ & 0,03 \\
\hline 12 & $\begin{array}{l}\text { Level 2. Kriteria Efektif - Sub Kriteria Menghentikan } \\
\text { Penyebaran Virus }\end{array}$ & 0,02 \\
\hline 13 & $\begin{array}{l}\text { Level 2. Kriteria Laporan Aktifitas }- \text { Sub Kriteria } \\
\text { Memberikan Notifikasi dari Virus yang Ditemukan }\end{array}$ & 0,03 \\
\hline 14 & $\begin{array}{l}\text { Level 2. Kriteria Laporan Aktifitas }- \text { Sub Kriteria } \\
\text { Menyediakan Hasil Scanning }\end{array}$ & 0,07 \\
\hline 15 & $\begin{array}{l}\text { Level 2. Kriteria Fitur - Sub Kriteria Real-Time } \\
\text { Scaneners }\end{array}$ & 0,01 \\
\hline
\end{tabular}


16 Level 2. Kriteria Fitur - Sub Kriteria Pemblokiran Script $\quad 0,01$

17 Level 2. Kriteria Fitur - Sub Kriteria Perlindungan Virus 0,03

18 Level 2. Kriteria Instalasi - Sub Kriteria Compatible $\quad 0,08$

19 Level 2. Kriteria Instalasi - Sub Kriteria Autoupdate $\quad 0,09$

Dapat disimpulkan bahwa perbandingan berpasangan yang diberikan responden memiliki nilai rasio konsisten secara umum sangat memuaskan karena tingkat konsistennya lebih kecil dari 0.10 sebagai batas maksimum nilai rasio konsisten. Dimana nilai inkonsistensi dari Level 1 Kriteria Mudah, Kriteria Laporan Aktivitas, dan Kriteria Instalasi mempunyai nilai konsistensi $(\mathrm{CI}=0)$, maka dapat diartikan pengambilan keputusan yang sangat konsisten. Sedangkan jika (CI > 0), maka pengambilan keputusan tidak konsisten (inkonsistensi). Maka harus dilihat kembali ratio CI dengan RI (RI = Random Indeks). Secara umum, tingkat konsistensi adalah memuaskan jika $(\mathrm{CI} / \mathrm{RI} \leq 0,10)$, tetapi sebaliknya jika $\mathrm{CI} / \mathrm{RI}$ $>0,10$ maka terdapat inkonsistensi yang serius dan hasil analisis AHP tidak ampuh dalam pengambilan keputusan.

\section{Interpretasi Penelitian}

Berdasarkan hasil kuesioner Pemilihan Software Antivirus untuk Laboratorium Komputer Akuntansi di SMK Jakarta IV dengan Menggunakan Metode AHP, didapat informasi bahwa AVG Antivirus merupakan perangkat lunak yang memiliki toolsatau fitur untuk lebih cepat menangani serta mendeteksi aktifitas-aktifitas antivirus yang berada di komputer. Dapat disimpulkan bahwa perangkat lunak yang berbasis antivirus yang tepat dan dapat diimplementasikan untuk laboratorium sekolah adalah AVG Antivirus. Dengan demikian dari hasil pengolahan data diatas dapat diambil informasi bahwa (H diterima).

\section{Implikasi Penelitian}

Dari hasil pengujian diatas dapat diambil berbagai implikasi penelitian yaitu dilihat dari Aspek Manajerial, Aspek Sistem, dan Aspek Penelitian lanjutan.

\section{Aspek Manajerial}

Berdasarkan hasil penelitian yang menyatakan bahwa software antivirus AVG adalah software antivirus yang paling cocok di implementasikan untuk laboratorium komputerakuntansi di SMK Jakarta IV, maka yang akan dilakukan oleh pihak sekolah adalah sosialisasi terhadap kepala sekolah, guru-guru, serta siswa/i yang menggunakan laboratorium komputer akuntansi sekolah, agar pelaksanaan praktikum di laboratorium komputer akuntansi sekolah memiliki acuan yang akan di implementasikan yantu Software AVG antivirus.

Seperti diketahui bahwa proyek implementasi software antivirus adalah bukan hanya sekedar pembelian software dan kemudian di instal, selesai, manajemen SMK Jakarta IV harus mempersiapkan tata laksana implementasi software antivirus, tentunya harus membentuk Koordinator Laboratorium Komputer Akuntansi atau kaprodi, khusus penanganan software yang mana kaprodi Laboratorium tersebut bertanggung jawab atas Laboratorium Komputer Akuntansi SMK Jakarta IV.

\section{Aspek Sistem}

Untuk menunjang pembelajaran di SMK Jakarta IV yang harus diperhatikan aspek sistem yang ada, aspek sistem tersebut meliputi :

Perangkat Hardware 
Perlu diperhatikan Personal Computer (PC) khususnya, apakah masih layak untuk pembelajaran, bila tidak layak tentunya harus dicari solusinya apakah harus di upgrade atau beli baru, agar software AVGantivirus saat di implementasikan untuk mendukung kegiatan belajar menganjar dengan baik.

Perangkat Software

Software antivirus yang ada perlu ditingkatkan kembali sesuai perkembangan teknologi dan kemampuan software antivirus dengan mengganti versi terbaru yaitu yang semula menggunakan antivirus versi lamadiganti dengan antivirus terbaru yang dapat mendeteksi keberadaan virus, menghapus/membersikan file-file yang terinfeksi virus, serta menghentikan penyebaran virus.

Infrastruktur Jaringan LAN (Local Area Network)

Infrastruktur jaringan LAN sudah ada menggunakan Network Operatig System (NOS) konektivitas dalam jaringan file server karena dengan infrastruktur jaringan tersebut memiliki manfaat yang diperoleh dari Network Operating System yaitu seluruh program terdistribusi dan diproses pada memori, perlu melakukan pemeliharaan infrastruktur jaringan LAN, agar proses avg antivirus dapat di implementasikan pada setiap Personal Computer $(P C)$ oleh para pengguna laboratorium komputer akuntansi di SMK Jakarta IV.

\section{KESIMPULAN DAN SARAN}

Dari 5 (lima) jenis software berbasis antivirus yaitu Kaspersky Antivirus, Eset Nod32 Antivirus, Avast Antivirus, Avira Antivirus, AVG Amtivirus, berdasarkan pengolahan data dari responden ahli menggunakan software Expert Choice 2000 didapat software AVG antivirus adalah software berbasis antivirus pilihan utama yang tepat di implementasikan untuk laboratorium komputer akuntansi sekolah SMK Jakarta IV, karena mempunyai nilai prioritas yang tinggi berdasarkan hasil penelitian dengan pendekatan Analytichal Hierarchy Process (AHP). Dari hasil analisa pendapat gabungan responden menunjukkan bahwa kriteria laporan aktivitas (nilai bobot 0,281 atau sebanding dengan $28,1 \%$ dari total kriteria) merupakan kriteria yang menurut responden paling penting dalam pemilihan software berbasis antivirus untuk laboratorium komputer akuntansi di SMK Jakarta IV, sub kriteria efektif (nilai bobot 0,220 atau sebanding dengan 22,0\% dari total sub kriteria dalam kriteria efektif) merupakan sub kriteria yang menurut responden paling penting, Sub kriteria instalasi (nilai bobot 206 atau sebanding dengan 20,7\% dari total sub kriteria dalam kriteria efektif), sub kriteria Fitur (nilai bobot 0,205 atau sebanding dengan 20,5\% dari total sub kriteria dalam kriteria egektid) merupakan sub kriteria yang menurut responden paling penting, sub kriteria mudah (nilai bobot 0,088 atau sebanding dengan 8,8\% dari total sub kriteria dalam kriteria egektid) merupakan sub kriteria yang menurut responden paling penting, Dari data tabel konsistensi perbandingan berpasangan dapat disimpulkan bahwa perbandingan berpasangan yang diberikan responden memiliki nilai rasio konsisten secara umum sangat memuaskan karena tingkat konsistennya lebih kecil dari 0.10 sebagai batas maksimum nilai rasio konsisten. Dimana nilai inkonsistensi dari Level 1 Kriteria Mudah, Kriteria Laporan Aktivitas, dan Kriteria Instalasi mempunyai nilai konsistensi $(\mathrm{CI}=0)$, maka dapat diartikan pengambilan keputusan yang sangat konsisten. Sedangkan jika (CI >0), maka pengambilan keputusan tidak konsisten (inkonsistensi). Maka harus dilihat kembali ratio CI dengan RI (RI $=$ Random Indeks). Secara umum, tingkat konsistensi adalah memuaskan jika (CI/RI $\leq 0,10)$, tetapi sebaliknya jika CI/RI > 0,10 maka terdapat inkonsistensi yang serius dan hasil analisis AHP tidak ampuh dalam pengambilan keputusan.

\section{DAFTAR PUSTAKA}

[1] Turban, E., Aronson, Jay E., Decission Support System and Intelligent Systems, Prentice Hall, Upper Saddle River, NJ, 1998 
[2] McLeod, Raymond, Jr, Sistem Informasi Manajemen. Jilid I dan II, terjemahan oleh Hendra Teguh(1998), PT.Buana Ilmu Populer, Jakarta.

[3] McLeod Jr, Raymond, Schell, George, Sistem Informasi Manajemen, Prentice Hall, Inv, 2004

[4] Indrajit., 2001, Analisis dan Perancangan Sistem Berorientasi Objek. Informatika, Bandung.

[5] Eriyanto, 1998. Analisa Sistem Industri Pangan. Pusat Antar Universitas Pangan dan Gizi. Institut Pertanian Bogor, Bogor.

[6] Marimin, Teknik dan Aplikasi Pengambilan Keputusan Kriteria Majemuk, Penerbit PT Grassindo, Jakarta.

[7] Turban, E., Decission Support System and Inteligent System, Prentice Hall, New Jersey, 2005.

[8] Saaty, T.L., 2001, Decission Making For Leader, Forth edition, University of Pittsburgh, RWS Publication.

[9] Saaty, T.L., 1988, Multicriteria Decission Making, The Analitychal Hierarchy Process. University of Pittsburgh, RWS Publication.

[10] Saaty, T.L., 1994, Fundamentals of Decission Making and Priority Theory with the Analytic Hierarchy Process, RWS Publications, Pittsburgh PA., 1994.

[11] Erikson S. Sinaga, Strategi Process Migrasi Proprietary Software ke Open Source Software Di Perusahaan Dengan Pendekatan Analitychal Hierarchy Process (AHP), Studi Kasus :SGU, Tangerang. Tesis di Magister Ilmu Komputer Universitas Budi Luhur Jakarta, 2008

[12] Ferry, Sisttem Penelitian dan Perencanaan Kinerja Perusahaan Menggunakan Metode Balance Scordard dan AHP. Tesis di Magister Ilmu Komputer Universitas Budi Luhur Jakarta, 2008.

[13] Dyah, Wulandari, Strategi IT Disaster Recovery Plan Pada Core Banking System dengan Pendekatan Analitychal Hierarchy Process, Studi Kasus : PT. Bank Mega Tbk. Tesis di Magister Ilmu Komputer Universitas Budi Luhur Jakarta, 2008

[14] Sarwindah, Kajian Pemilihan Software Desain Grafis untuk Pembelajaran Dengan Metode AHP (Analitychal Hierarchy Process), Studi Kasus : SMK Muhammadaiyah 9. Tesis di Magister Manajemen Universitas Budi Luhur Jakarta, 2011

[15] The Decision Support Software Company Decision Support Software,Inc.McLean.

[16] Suryadi, K. dan Ramdhani, MA.1998. Sistem Pendukung Keputusan. PT Remaja Rosdakarya, Bandung.

[17] Mulyono, Sri. 1996. Teori Pengambilan Keputusan. Jakarta: Fakultas Ekonomi Universitas Indonesia.

[18] Saaty, T.L. 1993. Pengambilan Keputusaan Bagi Para Pemimpin, Proses Hirarki Analitik untuk Pemngambilan Keputusan dalam Situasi yang Kompleks. Jakarta: PT.Pustaka Binaman Pressindo. 